\title{
A comparison of GHG emissions from UK field crop production under selected arable systems with reference to disease control
}

\section{Robert R Carlton - Jon S West - Pete Smith - Bruce DL Fitt}

RR Carlton $(\bowtie)$

Carlton Consultancy, La Mistrale, 26600 Erome, France;

e-mail: rob.carlton@carlton-consultancy.com

JS West, BDL Fitt ${ }^{*}$

Rothamsted Research, Herts. AL5 2JQ, UK

P Smith,

University of Aberdeen, Scotland AB24 3UU, UK

Current address: School of Life Sciences, University of Hertfordshire, Hatfield, Herts. AL10 9AB, UK

\begin{abstract}
Crop disease not only threatens global food security by reducing crop production at a time of growing demand but also contributes to greenhouse gas (GHG) emissions by reducing efficiency of $\mathrm{N}$ fertiliser use and farm operations and by driving land use change. GHG emissions associated with adoption of reduced tillage, organic and integrated systems of field crop production across the UK and selected regions are compared with emissions from conventional arable farming to assess their potential for climate change mitigation. The reduced tillage system demonstrated a modest (< $20 \%$ ) reduction in emissions in all cases, although in practice it may not be suitable for all soils and it is likely to cause problems with control of diseases spread on crop debris. There were substantial increases in GHG emissions associated with the organic and integrated systems at national level, principally due to soil organic carbon losses from land use change. At a regional level the integrated system shows the potential to deliver significant emission reductions. These results indicate
\end{abstract}


that the conventional crop production system, coupled to reduced tillage cultivation where appropriate, is generally the best for producing high yields to contribute to global food security and minimising greenhouse gas emissions, although there may be scope for use of the integrated system on a regional basis. The control of crop disease will continue to have an essential role in both maintaining productivity and decreasing GHG emissions.

Keywords: Arable farming systems - climate change mitigation - crop disease control - greenhouse gases - soil fertility - soil organic carbon

\section{Introduction}

Crop diseases directly threaten global food security by reducing food production (Fitt et al. 2011; Oerke 2006) in a world where more than 1 billion people currently do not have sufficient food (Anon 2009a). Since effects of diseases mean that there is less food to eat due to crop losses there is a need to increase food production by controlling crop diseases more effectively. Whilst the food security problems associated with crop diseases are now being made more acute by climate change (Garrett et al. 2006), the increasing world population will further increase the demand for food (Beddington 2010).

At a global scale climate change has already been linked to recent wheat and maize yield losses (Lobell et al. 2011) and has been cited as a probable factor in stagnation of cereal yields in France over the past decade (Brisson et al. 2010). In Denmark a similar stagnation in cereal yields has been linked to reduced use of fungicides and fertilisers, alongside increasing adoption of reduced tillage (Petersen et al. 2010). The importance of including crop diseases in climate change impact assessments is often ignored (Boonekamp 2011). Climate change may increase the severity and range of existing crop diseases or lead to the introduction of new diseases (Evans et al. 2008, West et al. 2012a). The threats of climate change to food security are particularly severe for farmers in the developing world (Schmidhuber and Tubiello 2007) and an expansion of arable land area in these regions would be expected to increase GHG emissions significantly (Carlton et al. 2010). 
As a result of these threats, there will be pressure on farmers in the developed northern Europe (Butterworth et al. 2010), to maintain current production and to produce more food to safeguard global food security (Mahmuti et al. 2009). To do this, it will be essential to incorporate methods to control existing and new disease problems into strategies for adaptation to impacts of climate change (Evans et al. 2008; Gregory et al. 2009; Barnes et al. 2010 West et al. 2012b).

Together with the requirement to maintain or increase food production in countries such as the UK, it is also essential to grow crops in such a way as to decrease emissions of greenhouse gases (GHG) as a contribution to climate change mitigation now. The UK Climate Change Act (2008) sets a UK greenhouse gas emissions reduction target of $80 \%$ by 2050 , based on 1990 levels. In 2008 agriculture accounted for $7.7 \%$ of UK GHG emissions (48 Mt $\mathrm{CO}_{2}$-e; DECC 2010) and these were primarily in the non- $\mathrm{CO}_{2}$ sector. As part of the overall $80 \%$ emissions reduction strategy the (UK) Committee on Climate Change is setting a target of a $70 \%$ reduction (51\% against current agricultural emissions) in the non $-\mathrm{CO}_{2}$ sector by 2050 (Committee on Climate Change 2010) and has identified technical abatement potentials for agriculture of 5-12 Mt $\mathrm{CO}_{2}-\mathrm{e}$, achievable by 2020 . However, the Department of Energy and Climate Change (DECC) has projected somewhat smaller short-term agricultural emission reductions (4\% on 2008 emissions; DECC 2010). Even if the more optimistic technical abatement potential is realised, there is still a significant shortfall from the 2050 target.

The major agricultural greenhouse gases are nitrous oxide $\left(\mathrm{N}_{2} \mathrm{O}\right)$ and methane $\left(\mathrm{CH}_{4}\right)$. In the UK, nitrous oxide is the more important, accounting for more than half of agricultural emissions (DECC 2010). To decrease the contribution of agriculture to global warming, there are many possible options (Smith et al. 2008). These include decreasing the use of fossil fuels and nitrogen fertilisers (and consequential production of $\mathrm{N}_{2} \mathrm{O}$ ), decreasing methane emissions from livestock and increasing the sequestration of carbon from the atmosphere (Glendining et al. 2009). There is considerable debate about whether the optimal way to decrease GHG whilst maintaining food production is through use of organic or conventional systems of crop production, including disease control. Measures that reduce crop yields (e.g. reduced use of fungicides and $\mathrm{N}$ fertilisers) are likely to result in an overall increase 
in GHG emissions due to an expansion of land under cultivation (Berry et al. 2010, practices associated with organic crop farming have the potential to sequester soil organic carbon in long-term arable land (Azeez 2009) and a reduction in inputs has also been linked to decreased emissions (Lin et al. 2011).

This paper addresses this debate by describing work that compares GHG emissions from UK field crop production under selected arable systems with reference to soil fertility and disease control.

\section{Methods}

\section{Different cropping systems used for comparison of GHG emissions}

This paper compares the annual GHG emissions from UK arable production under the conventional (current) crop production system with the emissions predicted assuming nationwide adoption of reduced tillage, organic or integrated arable systems whilst maintaining current crop production.

The conventional arable system reflects current arable production in the UK with figures based on 2005 - 2009 averages (unless otherwise stated). Covering a mixture of arable systems, it is largely dominated by relatively intensive crop production that aims to optimise production. This involves use of synthetic fertilisers to improve soil fertility and use of synthetic crop protection products to control weeds, pests and diseases. Diseases are controlled by a combination of breeding crop cultivars for resistance to the causal pathogens, cultural practices such as crop rotation and use of fungicides (Hughes et al. 2011). Under such a system, crops such as oilseed rape and wheat typically receive two or three fungicide applications per cropping season. For cereals, fungicide applications focus on protecting the uppermost leaves, which contribute most to the grain yield. For oilseed rape, some fungicides are applied in the autumn and winter against leaf and stem infecting pathogens such as Leptosphaeria maculans and Pyrenopeziza brassicae, while in many locations additional fungicide applications are made at flowering against Sclerotinia sclerotiorum. This use of fungicides occurs despite disease resistance being a component of cultivar selection for both cereals and oilseed rape, because no cultivar is completely resistant to all diseases. While a significant proportion 
(27\%) of UK arable land is not in crop production in any given year, cropping intensities are much greater $(>90 \%)$ in the more productive areas (e.g. East of England region). Land use, inputs (fertiliser, fungicide and other crop protection products) and production figures are derived from Defra (2005, 2006, 2007, 2008, 2009a, 2009b) data.

The reduced tillage arable system is similar to conventional crop production with the exception that reduced tillage methods are adopted wherever practical. It is assumed that reduced tillage approaches are not employed for crops requiring considerable soil cultivation, such as potatoes, sugar beet or a number of smaller crops grouped together for the purposes of this paper as 'other crops' including several vegetables requiring intensive mechanical cultivation (e.g. carrots, parsnips, onions). Whilst methods of crop disease control used are similar to those in the conventional system, crop debris on the soil surface can provide a potent source of air-borne pathogen inoculum to start disease epidemics in autumn (West and Fitt 2005; Fitt et al. 2006) and it is more difficult to effectively control diseases in this system, even with increased use of fungicides. Reduced tillage also has the potential to make weed control more difficult and it is assumed that herbicide usage is increased by a nominal $50 \%$ to compensate for this. Land use, inputs (other than herbicides) and production figures are assumed to be identical to those of conventional crop production. Emissions associated with cultivation are reduced in order to reflect reduced operations. Reduced cultivation is also assumed to augment soil organic carbon (SOC, Smith et al. 2008).

The organic arable system assumes that there is no application of synthetic crop protection products or synthetic fertilisers. Fertility enhancing periods are included in the crop rotations and are assumed to account for $50 \%$ of the croppable land in the UK and in the North West region; and $25 \%$ of the croppable land in the East of England region. These periods can contribute to control of many diseases with epidemics started by inoculum produced on crop debris, such phoma stem canker of oilseed rape. Less intensive rotations help to reduce the build-up of inoculum and lengthy fertility enhancing periods allow for more complete microbial degradation of the inoculum in the soil (West et al. 2001). Disease is primarily achieved through cultivar resistance (Lampkin et al. 2008). Inputs such as sulphur are rarely employed (Lampkin et al. 2008) and are not accounted for in the 
calculations. Crop yields are based on data reported for England and Wales in 2006 (Jones and Crane 2008). Land use change from pasture to arable is envisaged in order to maintain overall crop production at its current level.

Under the organic system the average annual maximum available $\mathrm{N}$ is assumed to be $100 \mathrm{~kg} \mathrm{~N} \mathrm{ha}^{-1}$ (derived from data in Rayns et al. 2009) during crop production periods of the rotation (i.e. over 3 years). It is assumed that $14 \mathrm{t} \mathrm{N}$ is made available in grass/clover leys each year through the application of farm-yard manure (FYM) (Berry et al. 2002). The two main factors affecting yields in organic crop production are reduced availability of nitrogen (Berry et al. 2002) and the absence of fungicides plus other synthetic crop protection products. It was assumed that these two factors are of approximately equal weight and that for those crops where $\mathrm{N}$ is not considered to be limiting (sugar beet, peas and beans) organic yields are closer to conventional yields. Fertility enhancing rotations and use of organic manures are assumed to augment soil organic carbon on long-term arable land (Azeez 2009). Land use change (LUC) is assumed to deplete soil organic carbon (Carlton et al. 2010).

The integrated crop production system integrates the high yields of conventional crop production with the SOC sequestration of organic crop production, employing fertility enhancing rotations and use of organic manure to augment soil organic carbon, but allowing use of additional synthetic fertilisers, fungicides for disease control and other crop protection products to achieve conventional crop yields. Land use change from pasture to arable is envisaged to maintain current levels of production. Azeez (2009) indicates that where organic and non-organic farms share similar rotations and use of organic manures little difference in SOC has been be observed. For this reason, the impacts of integrated crop production on soil organic carbon are assumed to be the equivalent to those of the organic system.

\section{Calculation method}

The approach taken involves seven steps to ascertain the emissions that would be expected to follow nationwide adoption of each given agricultural practice.

1. Determination of current UK field crop production, the area under crops and area currently suitable for cropping (croppable area). 
2. Determination of area of arable land needed under each agricultural system to maintain current UK field crop production.

3. Determination of the area of pasture that would need to be converted to arable land under each agricultural system to maintain current UK field crop production (it is assumed that yields on converted pasture would equal conventional yields).

4. Calculation of crop specific emissions (carbon footprints) under each agricultural system.

5. Calculation of the total emissions associated with crop cultivation under each agricultural system.

6. Determination of impact of the agricultural system on $\mathrm{SOC}$ balance on longterm arable land.

7. Determination of the impact of LUC on SOC balance on the areas of pasture converted to arable land.

8. Addition of crop specific emissions (4), soil carbon sequestration (6) and soil carbon emissions (7).

\section{Crop production and area data (step 1)}

Data on area planted, yield and production have been compiled for UK field crops. Small crops (in terms of area planted) are grouped together under one category named 'other crops'. Five year averages are generated from annual data for the years 2005 - 2009 (DEFRA 2009b).

\section{Area calculations (steps 2 and 3 )}

The two factors that influence the area under each crop for a given system are the crop yield and cropping intensity. The yield ratios are given as a proportion of conventional yields. Yields under conventional, reduced tillage and integrated crop production were assumed to be equal $($ ratio $=1)$ as all three systems allow the use of synthetic fertilisers and all registered crop protection products. Where data are available, organic crop yields were based on 2006 values from Jones and Crane (2008), with the exception of sugar beet. In the case of sugar beet, their data indicate that organic yields are greater than conventional yields but they are based on a very small sample and are not considered to be reliable (Jones and Crane 2008). Average applications of $\mathrm{N}$ fertilisers to sugar beet and 'other crops' are 
relatively small (<100 $\mathrm{kg} \mathrm{N} \mathrm{ha}^{-1}$; DEFRA 2009b) and close to the expected range of be a major yield limiting factor under organic production. Since this has similarities to pea and bean crops, which have an organic / conventional yield ratio of 0.83 (Jones and Crane 2008), this yield ratio is assumed for sugar beet and 'other crops'. In other cases where there are no reliable yield data for a crop the organic/conventional yield ratio is assumed to be 0.7 (organic yield $=0.7 \times$ conventional yield).

The area for a given crop associated with a system was calculated using the following formula:

$$
I C A_{A S}=I C A_{C F} / I C Y R_{A S}
$$

\{equation 1\}

where $I C A_{A S}$ is the individual crop area for the agricultural system in question, ICA is the individual crop area under conventional crop production and ICYR $R_{A S}$ is the individual crop yield ratio for that crop under the agricultural system in question. The yields ratios are given in Tables 2 (UK), 5 (East of England region) and 6 (North West region).

Cropping intensity is the proportion of arable land under crop each year. This was determined for conventional crop production from DEFRA data (DEFRA 2009b). Cropping intensities for conventional crop production are 73\% (UK), 93\% (East of England region) and 53\% (North West region). Cropping intensity for reduced tillage crop production was assumed to be equal to that of conventional crop production. Cropping intensities under organic practice are typically less than those under conventional crop production since organic rotations include fertility building periods where the land is under grass and/or clover (grass/clover leys). Organic cropping intensities were assumed to be 50\% (UK and North West region) and $75 \%$ (East of England region) based on organic practice (Lampkin et al. 2008). Cropping intensities of integrated and organic crop production were assumed to be the same.

The area of arable land that is not under crops in conventional crop production was obtained from DEFRA statistics (DEFRA 2009b) and the corresponding area under reduced tillage crop production was assumed to be the same. The area of arable land thatis not under crops under organic crop production and integrated crop production is calculated using the following formula: 
where $\mathrm{NCA}_{\mathrm{AS}}$ is the area of the specific agricultural system which is not cropped each year, ICA $A_{A S}$ are the areas of the individual crops under the specific agricultural system and $\mathrm{CIR}_{\mathrm{AS}}$ is the cropping intensity ratio for that agricultural system.

The overall area for a specific agricultural system is calculated using the following formula:

$$
\left.A A_{A S}=\sum\left(W A_{A S}, B A_{A S}, O A_{A S}, S B A_{A S}, O s r A_{A S}, P A_{A S}, N C A_{A S}\right) \text { \{equation } 3\right\}
$$

where $A A_{A S}$ is the arable area under the agricultural system, $W A_{A S}$ is the area under wheat, $\mathrm{BA}_{\mathrm{AS}}$ is the area under barley, $O \mathrm{~A}_{\mathrm{AS}}$ is the area under oats, $\mathrm{SBA}_{\mathrm{AS}}$ is the area under sugar beet, OsrA $A_{A S}$ is the area under oil seed rape, $P A_{A S}$, is the area under potatoes and $\mathrm{NCA}_{\mathrm{AS}}$ is the area that is not cropped each year under that system.

The additional area needed to maintain current production under a given agricultural system is calculated by subtracting the conventional crop production arable area from the calculated arable area for the given agricultural system.

\section{Calculations of crop specific, short-term pasture and grass/clover ley GHG emissions (step 4)}

A carbon footprint has been determined for major UK crops on a per-hectare basis following the approach of Berry et al. (2008). Manufacturing costs (inputs plus equipment) are included in order to generate life cycle (cradle to farm gate) emissions. Input data and emission factors are given in Appendix 1. Background $\mathrm{N}_{2} \mathrm{O}$ emissions are excluded following the approaches adopted by Berry et al. (2008), Mahmuti et al. (2009) and Hughes et al. (2011).

Emissions associated with soil organic carbon are omitted from the crop specific emission calculations but are accounted for in steps 6 and 7 .

\section{Calculation of total crop, short-term pasture and grass/clover ley GHG emissions (step 5)}

For a given agricultural system, the GHG emissions for each crop are calculated by multiplying the crop specific emissions by the area under the crop. The GHG emissions for the non-crop cover (grass and grass/clover leys) are calculated by 


$$
A E_{A S}=\sum\left(I C E_{A S} \times A_{A S}\right)
$$

\{equation 4$\}$

where $A E_{A S}$ is the total emissions from the agricultural system, $I C E_{A S}$ is the emissions for each of the various crops and $A_{A S}$ is the area of each crop.

\section{Calculation of SOC impacts (steps 6 and 7)}

Pastures typically have greater levels of SOC than neighbouring arable land and cultivation of pasture is associated with depletion of SOC (Carlton et al. 2010, Guo and Gifford 2002, Smith 2008, Smith et al. 2008, 2010). Some arable practices, including fertility building rotations, application of farmyard manure and avoidance of tillage, have been shown to increase levels of SOC in long-term arable land (Azeez 2009, Smith et al. 2008). Since the rates of carbon sequestration or depletion associated with a management practice are not linear, the factors used are given on an annual mean basis, using information for the first 20 years following introduction of a practice.

Organic management practices and reduced tillage were assumed to augment SOC levels on pre-existing arable land. Where it was determined that additional arable land would be required to maintain conventional levels of production, it was assumed that long-term pasture would be converted to arable land with consequential depletion of SOC (Table 1).

Table 1 near here.

To calculate the impact of SOC changes, the relevant factor for each practice was multiplied by the corresponding land area. For example, under organic practice pre-existing arable land was assumed to gain $0.56 \mathrm{t} \mathrm{C} \mathrm{ha}^{-1} \mathrm{y}^{-1}$ whilst pasture converted to arable land was assumed to lose $1.8 \mathrm{t} \mathrm{C} \mathrm{ha}^{-1} \mathrm{y}^{-1}$.

\section{Calculation of overall GHG emissions associated with each agricultural system (step 8)}

Total emissions were calculated by summing the crop, non-crop and SOC carbon fluxes. 


\section{Results}

\section{Calculations of GHG for the UK for each system}

The arable area needed to maintain average UK arable crop production is influenced by crop yields and cropping intensity. The total average UK arable area is currently greater than $6 \mathrm{M}$ ha (Table 2), with a cropping intensity of $72 \%$ (i.e. in any year $72 \%$ of the arable area is planted with cash crops). To maintain conventional levels of production, the arable areas needed under the integrated system and the organic system were considerably greater than that needed under conventional crop production. In the case of the integrated system the area under each crop was unchanged, since there is no impact on yields. However, the adoption of a $50 \%$ fertility enhancing rotation increased the arable area by $2.7 \mathrm{M}$ ha. The area of organic arable land was more than double the conventional arable area as a result of the combined impact of smaller yields, which increased the area under crops by 1.9 $\mathrm{M}$ ha, and the adoption of a $50 \%$ fertility enhancing rotation, which increased the area from 6 to more than $12 \mathrm{M}$ ha.

Table 2 near here

The GHG emissions associated with conventional wheat, barley and oilseed rape (Table 3) were similar to published figures (Berry et al. 2008, Mahmuti et al. 2009, Carlton et al. 2010, Hughes et al. 2011). In most conventional crops, synthetic $\mathrm{N}$ fertiliser manufacture is the largest single component, contributing between $20 \%$ and $40 \%$ of emissions. Peas and beans are an exception since they derive $\mathrm{N}$ from associated nitrogen fixating bacteria. Emissions from reduced tillage crop production were slightly less than those from conventional production since costs associated with tillage (diesel and equipment) were less in cereals, oilseed rape, peas and beans. For those crops that are unsuitable for reduced tillage, cultivation emissions were identical to those from conventional systems.

Table 3 near here.

When determined on a per-hectare basis, integrated crop-specific emission figures were generally less than the corresponding conventional crop figures since the fertility enhancing rotations reduced the need for synthetic fertiliser; decreasing fertiliser production GHG emissions. For the same reason, organic crop-specific 
emissions were generally the smallest since no synthetic $\mathrm{N}$ fertilisers are used. Peas fertilisers in these crops are small, and application of lime, with corresponding in-field $\mathrm{CO}_{2}$ emissions, is more intensive under organic management systems.

Conventional, reduced tillage and integrated crop production systems had identical areas under each crop, and relatively small differences in crop related emissions, resulting in similar overall emissions from crop cultivation (Table 4). Although organic crop specific emissions were generally the smallest on a per ha basis, the area under organic crops was greater than under other systems, resulting in the greatest total crop emissions.

Table 4 near here.

Changes in SOC have considerable potential to influence emissions, as demonstrated by the combined impact of total crop emissions, SOC sequestration on long-term arable land and SOC depletion on converted pasture (Table 4). No SOC effects were assumed for conventional crop production, and all emissions were related to crops. Reduced tillage crop production had slightly smaller emissions, principally due to SOC sequestration. Integrated crop production had a greater reduction in crop specific emissions, due to reduced need for synthetic $\mathrm{N}$ fertiliser. There was a large impact from SOC sequestration on existing arable land but an even larger impact from SOC depletion due to the conversion of 2700 ha pasture to arable land. When combined, the SOC changes result in net increases in emissions. Net emissions from SOC are considerably greater under organic production because the rate of SOC depletion is more than four times greater than the SOC sequestration rate, although the areas of long-term arable land and converted pasture were roughly equal,.

Under conventional production, $\mathrm{N}$ fertilisers (manufacture and soil emissions) account for $66 \%$ of emissions with another $20 \%$ from operations (Figure 1a). Emissions associated with manufacture of $\mathrm{N}$ fertilisers are smaller under integrated production, although this is more than compensated for by the additional net SOC change emissions (Figure 1b). Under the organic management system, there are no emissions from $\mathrm{N}$ fertiliser manufacture and SOC change is the largest source, accounting for $64 \%$ of emissions (Figure 1c). The proportions of emissions from 
other sources are reduced, although in absolute terms organic $\mathrm{N}_{2} \mathrm{O}$ emissions are greater.

Figure 1 near here.

The overall impact on crop emissions and changes in SOC (Figure 2) suggest that reduced tillage produces slightly smaller emissions than conventional crop production. Emissions associated with UK wide adoption of organic crop production are approximately three times greater than those of conventional crop production, principally as a result of SOC depletion associated with land use change. The same factor has an impact on integrated crop production, although the impact of land use change is smaller and the sequestration benefits on long-term arable land compensate for much of the SOC depletion.

Figure 2 near here.

\section{Comparison of the East of England region and North West region}

The average arable area of the East of England region is greater than $1 \mathrm{M}$ ha (Table 5), $94 \%$ of which is under cash crops each year. Assuming a $75 \%$ cropping intensity under integrated and organic systems, the areas needed to maintain production would be increased by $24 \%$ and $85 \%$ respectively. The overall emissions (Figure 3 ) indicate that emissions from organic crop production in the East of England region would be more than double the emissions from conventional crop production. Both reduced tillage crop production and integrated crop production (the SOC benefits on long-term arable land were greater than the losses associated with conversion of pasture) show a small reduction in emissions.

Table 5 near here

Figure 3 near here.

The total average North West region arable area is slightly less than 200,000 ha (Table 6), with a cropping intensity of $53 \%$. The areas needed to maintain current production would be, respectively, 11,000 ha or 62,000 ha larger under integrated crop production or organic crop production. However, the calculations indicate that emissions from organic crop production in the North West region would be almost 
$30 \%$ smaller than the emissions from conventional crop production, principally due to Reduced tillage crop production also showed a small reduction in emissions. The largest reduction was for integrated crop production since there was little need for pasture conversion, thus minimising SOC depletion whilst gaining the full benefit of SOC sequestration. This analysis suggests that adoption of an integrated system of crop production could decrease emissions by more than $80 \%$ in the North West region.

\section{Table 6 near here}

Figure 4 near here.

The East of England region analysis suggests that GHG emissions from integrated crop production would be slightly smaller than emissions from conventional production. The integrated production cropping intensity is assumed to be greater $(75 \%)$ so, unlike the UK wide analysis, there is little scope to increase this parameter. Furthermore, the high cropping intensity does raise questions about whether sufficient FYM would be available and whether the default SOC sequestration rate would be achievable. Therefore, this result should be treated with caution. The same issues affect organic production, which already appears to be at a distinct emissions disadvantage based on the default analysis. Reduced tillage production does show a benefit and is appropriate for more than $80 \%$ of the crops by area. Since the uncertainties concerning $\mathrm{N}_{2} \mathrm{O}$ emissions are likely to be of less significance given the warmer drier conditions associated with this region, these results suggest that uptake of this system of crop husbandry in the region would be beneficial.

The North West region analysis shows a benefit for all three alternative systems over conventional crop production. Integrated crop production appears to deliver the most significant emission benefits. However, this result should be treated with caution because a high proportion of arable land in the region is usually under short-term pasture, fallow or mixed farming (arable plus livestock). Thus, the rate of SOC sequestration under integrated (and organic) production may be overestimated. Organic production shows smaller GHG emissions than both conventional and reduced tillage production, principally due to the low conventional cropping intensity 
in the region combined with the SOC benefits, although the caveat raised above in reduced tillage is suitable throughout the region, given the relatively high rainfall, which increases the risk of $\mathrm{N}_{2} \mathrm{O}$ emissions; thus this system may offer little real advantage over conventional production.

\section{Sensitivity analysis (UK calculations)}

There are four uncertain factors that have a large impact on the results of these analyses. These are the cropping intensity, the rate of SOC depletion on conversion of pasture to arable land, the rate of SOC sequestration on long-term arable land under organic and integrated systems and the yield ratio between organic and conventional cropping systems. Cropping intensity under organic systems reflects the need to increase soil nitrogen through fertility-enhancing periods that reduce cropping intensities. While a $50 \%$ cropping intensity is assumed (i.e. $50 \%$ of land is under fertility-enhancing periods), the cropping intensity could be increased if shorter fertility-enhancing periods were able to generate sufficient available N. Were a cropping intensity of $66 \%$ ( 4 years of crops and 2 years of grass/clover leys) to be assumed, with all other variables unchanged, analysis indicates that UK emissions from organic and integrated arable production would be $155 \%$ and $28 \%$ of conventional arable emissions, respectively. While organic crop production continues to have increased emissions, under these conditions integrated crop production shows a major emissions advantage over conventional production. However, it should be noted that these figures assume that SOC sequestration remains constant irrespective of cropping intensity.

Assuming that a simple arithmetic relationship can be applied to SOC depletion rates and SOC sequestration rates (Table 1), there was a depletion rate of $1.8 \mathrm{t} \mathrm{C} \mathrm{ha}^{-1} \mathrm{y}^{-1}$ associated with pasture to arable conversion under organic and integrated crop production. However, Kirchmann et al. (2007) found that, after conversion of grassland to organic or conventional mixed farming in Sweden, SOC losses under organic management were less than half the corresponding losses from conventional management. Were a similar relationship to be found in the UK, the emissions assumed would be an over-estimate and the emissions associated with LUC in under the organic and integrated systems would be smaller. Assuming all 
other factors remain constant, at an SOC depletion rate of $1.38 \mathrm{t} \mathrm{C} \mathrm{ha}^{-1} \mathrm{y}^{-1}$ the GHG conventional crop production; were the rate of depletion to be any smaller, integrated crop production would have a net emissions advantage. To match conventional system GHG emissions under the organic system, the SOC depletion rate would have to be reduced to $0.45 \mathrm{tha}^{-1} \mathrm{y}^{-1}$.

Changing the assumed rate of $\mathrm{SOC}$ sequestration has a smaller impact on the results. At a $50 \%$ cropping intensity, a sequestration rate of $2 \mathrm{t} \mathrm{C} \mathrm{ha-1} \mathrm{y}^{-1}$ would be necessary to bring the organic emissions close to conventional emissions and at $66 \%$ cropping intensity the equivalent figure is $0.94 \mathrm{t} \mathrm{C} \mathrm{ha}^{-1} \mathrm{y}^{-1}$. The same calculation for integrated crop production indicates a sequestration rate of $0.75 \mathrm{t} \mathrm{C} \mathrm{ha}^{-1} \mathrm{y}^{-1}$ is needed to match conventional production, assuming a 50\% cropping intensity. However, at a $66 \%$ cropping intensity integrated production has smaller emissions than conventional production and the sequestration rate could be $<0.05 \mathrm{tC} \mathrm{ha}^{-1} \mathrm{y}^{-1}$ and still deliver a benefit in terms of decreased emissions.

The organic/conventional cropping yield ratios are based on a single year and it is possible that these are unrepresentative and under-estimate the productivity of organic systems. Furthermore, the disparity between organic and conventional yields could diminish with improved organic cultivars and agronomic practices. If the organic/conventional yield ratio changed from the given range (Table 2) to 0.85 for all crops, GHG emissions associated with organic production would be reduced by $37 \%$, although these GHG emissions would still be the largest amongst the four systems investigated. To match the emissions associated with the integrated system, organic yields would need to be more than $95 \%$ of conventional yields with no corresponding increase in soil nitrogen concentrations.

\section{Feasibility and uncertainties}

Nationwide adoption of organic crop production combined with maintenance of current total UK production is clearly unfeasible since there is insufficient suitable land to double the current arable land area. Even at the higher (66\%) cropping intensity investigated in the sensitivity analysis, this would require an additional 3400 ha of arable land. National adoption of integrated crop production based on the default assumptions would require a $48 \%$ expansion in arable land, which is also 
unrealistic. At a $66 \%$ cropping intensity, integrated crop production would require an additional $0.6 \mathrm{M}$ ha of arable land, the overall area being similar to the UK arable area in 1990 (FAOSTAT 2011). While some of the arable land lost since 1990 may not be available for re-cultivation, the area of long-term pasture has increased by $0.6 \mathrm{M}$ ha since 2000 (FAOSTAT 2011) suggesting that conversion of this area to arable land could be feasible. Furthermore, if the pasture used has only recently been converted from arable land this would engender smaller SOC losses than conversion of longterm, permanent pasture, because it takes many decades for SOC to accumulate after conversion from arable land (Smith 2008).

The three main factors contributing to SOC sequestration are fertilityenhancing grass/clover leys, use of composted manure (FYM is the most common type) and use of plant based organic manure (Azeez 2009). However, the latter has a relatively small impact on soil organic matter (Raupp and Oltmanns 2006); stockless organic systems that rely on plant-based organic manures tend to have lower SOC concentrations than mixed organic farms (Azeez 2009). These findings suggest that the fertility enhancing periods and use of FYM are the more important components associated with $\mathrm{SOC}$ sequestration.

One uncertainty is whether the SOC benefits determined by Azeez (2009) could be attained with shorter fertility-enhancing periods than the 3 years of grass/clover leys in a six year rotation assumed. While the role of fertility-enhancing in organic rotations is principally to augment soil $\mathrm{N}$, in the integrated system this is less important because synthetic fertilisers can be used. As a result, the importance of fertility-enhancing periods under integrated crop production is in the SOC sequestration potential. The sensitivity analysis indicated that this system could produce a net-emission benefit with a ten-fold reduction in SOC sequestration. Therefore, long fertility-enhancing periods are probably not critical to integrated crop production and a $66 \%$ cropping intensity is likely to be both feasible and to deliver an emission benefit.

Another uncertainty is whether crop production based on an average cropping intensity of $66 \%$ could provide sufficient FYM in all regions. The application of farmyard manure to all arable land would require livestock production in all regions (assuming long distance transport of FYM is impractical) and grass/clover leys would 
generate grazing land for livestock (the emissions associated with livestock grazing are not considered in this paper). An overall $66 \%$ cropping intensity scenario would continue to include a range of cropping intensities and grazing land would continue to be limited in the parts of the country (e.g. in the East of England region if a 75\% cropping intensity was adopted there). This would not necessarily be a limitation if pasture grazing was supplemented by sufficient alternative feedstock, assuming that this could be supplied with no further increase to the arable area.

It is not clear what impact conversion of long-term pasture to arable land would have on livestock farming. Both the organic and the integrated scenarios assume not only large-scale expansion of croppable area in place of of long-term pasture but also an increase in the area of short-term grassland. While the total area of grassland would remain constant (integrated) or be slightly reduced (organic), it is possible that short-term pasture could become more productive in terms of grazing due to improved management practices. In this case, there would be less need for supplementary feed for livestock, reducing both the area under crops and the overall emissions, although this would be unlikely to have a significant impact on gross emissions.

It was assumed that there are no SOC related emissions from long-term arable land. While agricultural intensification in the UK started in the 1940s, the longterm impact of these changes on SOC may still be occurring (Smith et al. 2010). The UK 2009 greenhouse gas inventory (DECC 2011) indicates $0.4 \mathrm{Mt} \mathrm{CO}_{2}$-e emissions from remaining cropland which is not accounted for here. However, inclusion of this figure would have a negligible impact on the outcome of this work.

\section{Discussion}

This analysis suggests that conventional farming, plus reduced tillage cultivation where appropriate, can best contribute to the achievement of government GHG emissions targets by 2020 (Committee on Climate Change 2010). These include the use of cultural practices, disease-resistant crop cultivars and fungicides to control diseases and increase yields. It has been estimated that disease control by fungicides on wheat, barley and oilseed rape saves more than $1.5 \mathrm{Mt} \mathrm{CO}_{2}$-e emissions each cropping season (Figure 5; Hughes et al. 2011). This saving is associated with increased yield and therefore better use of $\mathrm{N}$ fertiliser per $\mathrm{t}$ of crop 
produced. Furthermore such disease control not only contributes to climate change increase food production in areas such as northern Europe that may benefit from climate change (Beddington 2010, Butterworth et al. 2010) to avoid starvation in other areas of the world that may suffer worse food insecurity as a result of climate change (Schmidhuber and Tubiello 2007, Stern 2007). There is thus a need to develop strategies for adaptation to climate change that include improved disease control to decrease waste and increase yields, through development of more effective fungicides and crop cultivars with improved resistance that can operate at higher temperatures against the pathogens that are likely to be most important (Oerke 2006, Evans et al. 2008, Barnes et al. 2010, Fitt et al. 2011, West et al. 2012a).

The analysis indicates that there is relatively limited scope to reduce agricultural emissions through nationwide adoption of either organic or integrated systems in place of the conventional system. However, this conclusion is sensitive to the defaults used in the analysis and it is possible that the integrated system may have potential to significantly reduce GHG emissions.

Figure 5 near here

Widespread adoption of the reduced tillage system has the potential to deliver a moderate benefit (15\% reduction in emissions). While the benefit would contribute to emission reduction targets over the next 10 years, it could provide only a part of long-term emissions reductions. Reduced tillage can also reduce soil water losses (Smith 2008, Smyth et al. 2011) and this is likely to be increasingly important in the south and east of England where drier summers are predicted as a result of climate change (UKCP09). This practice may not be suitable in all conditions so UK-wide adoption is unlikely. Under wet conditions and in poorly drained soils, the risk of $\mathrm{N}_{2} \mathrm{O}$ emissions increases (Smith et al. 2001) and this source of GHG emissions could easily outweigh the SOC benefits. Furthermore, if reduced tillage were not adopted throughout the rotation cycle (i.e. for all crops) the sequestration benefits accrued during cultivation of reduced tillage crops could be largely lost during cultivation of crops when conventional tillage would be employed, resulting in little or no net benefit through a complete rotation cycle (Smith et al. 1998). The reduced tillage system is 
also likely to increase the severity of disease epidemics since many arable crop diseases in Europe are started in autumn by inoculum produced on crop debris (Fitt et al. 2006), with potential decreases in yield and crop production unless fungicide use is increased. Another potential disadvantage of reduced tillage is that weed control may be decreased, even with increased use of herbicide. In Canada, where reduced tillage is in widespread use in crops such as spring oilseed rape (Smyth et al. 2011), this is usually associated with herbicide-tolerant cultivars, which aids weed control. In the UK, herbicide tolerant crop cultivars are not widely available and current authorisations for some herbicides may be cancelled following implementation of regulation EC 1107/2009 (PSD 2009); thus weeds such as black grass in cereals could present an increased threat to yields were reduced tillage to be widely adopted although agronomic management strategies may be developed to address this.

The results of this work indicate that widespread adoption of the organic crop production system cannot maintain current crop production without substantial increases in GHG emissions. National adoption of the organic system in the UK would require a doubling of arable land to maintain production. Were this a practical proposition, $>6 \mathrm{M}$ ha of pasture (or forest) would need to be converted to arable land in order to maintain production levels and this would entail very large emissions from SOC depletion. It is notable that even when SOC changes are excluded, the overall organic crop system GHG emissions are slightly greater than those of the conventional system, despite the small individual crop-specific emissions per ha. Furthermore, even it were feasible, such a major change of land use would decrease areas available as habitats for wildlife and reduce biodiversity. Emissions associated with conversion of pasture in the UK are very large (Carlton et al. 2010) and have a major impact on this analysis. Thus, management systems that decrease productivity per ha and lead to expansion of the arable area, either through reduced yields or through reduced cropping intensity, increase overall GHG emissions. The relationship between crop yields and GHG emissions has been investigated (Burney et al. 2010, Carlton et al. 2010), specifically with reference to fungicides in wheat (Berry et al. 2008, 2010), oilseed rape (Mahmuti et al. 2009) and barley (Hughes et al. 2011). The absence of fungicides in the organic system would not only increase GHG emissions through the resulting decrease in yield but also increase amounts of 
pathogen inoculum available to start epidemics in successive cropping seasons (West et al. 2001), since neither crop rotation nor disease-resistant cultivars currently provide complete control of crop diseases in the UK. This study may under-estimate the current organic to conventional yield ratios and higher ratios for a number of developed countries have been reported (Bagley et al. 2007). Furthermore, development of higher yielding organic crop cultivars is possible. However, the sensitivity analysis indicates that organic yields would need to be similar to conventional yields to match the emissions of the integrated crop production system, and such a yield improvement would need to be combined with relatively short fertility building periods to reduce the emissions to a figure close to that of the conventional system. Overall, therefore, there were no feasible parameters that allowed organic crop production to match any of the other systems on the basis of GHG emissions, given the reported rates of GHG emissions associated with SOC depletion following conversion of pasture to arable land. However, this conclusion is specific to the UK and whilst it may be relevant to countries with similar agriculture it does not follow that the role of organic farming is similarly limited in developing countries. Adoption of organic farming in regions such as sub-Saharan Africa may improve food security at a local level (Halberg et al., 2006) and organic practice has the capacity to increase conventional yields by more than $150 \%$ in developing countries (Bagley et al., 2007).

The integrated crop production system may offer emissions benefits at national level, although this would require further research on the relationship between SOC sequestration and cropping intensity. A further factor that could favour adoption of integrated crop production would be benefits to soil structure. Improved soil structure stability resulting from increased soil organic matter would be expected to improve crop yields (Low 1973, Lal 2004) and may also reduce $\mathrm{N}_{2} \mathrm{O}$ emissions by improving drainage. However, applications of FYM are an important component of the integrated system, increasing SOC and, given the rapid development of on-farm biogas production which may compete with FYM for livestock excreta, it would be prudent to compare the GHG emission benefits of FYM on SOC against the benefits of biogas fuel generation. Less intensive crop rotations might also reduce the incidence of disease and pest infestations and thereby increase yields, reducing emissions in the integrated system. However, the 
integrated crop production system with the shortest fertility building periods resulted in the lowest emissions, yield increases associated with more extensive rotations are unlikely to significantly alter the conclusions.

An assumption pertaining to this work is that it is important to maintain productivity in the UK, and by implication in the developed world, to safeguard global food security. Alternatively, Lin et al. (2011) suggest that there is capacity in the developing world to meet the growing demand for food even if there were to be a decrease in production in the developed world. Furthermore, Chapelle and LaValle (2011) argue that resource inefficiency and environmental and health impacts make conventional farming a luxury we can no longer afford. With the exception of GHG emissions, it is outside the scope of this paper to discuss wider environmental and health issues although it should be noted that climate change represents a very significant risk to both biodiversity (IPCC 2002) and human health (WHO 2011).

The global population is expected to increase by 2 billion by 2050 with almost all that growth in developing countries (UN 2011), the largest growth being expected in Africa. In many of the least developed countries, the majority of which are in subSaharan Africa, populations are predicted to double by 2050. The average per capita calorific intake is expected to increase in developing countries (Bruisma 2009), the proportion of meat in the diet of developing countries is also increasing (FAO 2006) and meat typically requires more land than crops on a weight for weight basis (Rosengrant et al. 1999). Thus, the demand for food is likely to increase more rapidly than population growth and is likely to more than double in large parts of subSaharan Africa by 2050.

Predictions about the ability of developing countries to meet the growing demand for food differ. FAO (2002) states that developing countries will become increasingly dependent on cereal imports between 2015 and 2030 whereas Betru and Kawashima (2010) indicate many, though not all, African countries have the capacity to meet increasing demand for cereals during the same period through increasing production. While most increased production will result from productivity improvements, arable land expansion in developing countries is expected to account for $12 \%$ of the increase (120 M ha; Bruinsma 2009) with consequential impact on GHG emissions (Carlton et al. 2010), although this may be partially offset by 
reforestation in the developed world. It is generally agreed that, while there is clear potential to improve productivity in developing countries, this will require the appropriate socio-economic and political conditions (Bruinsma 2009, Betru and Kawashima, 2010). Given the uncertainties about the potential to meet increasing demand for food through productivity increases in developing countries and about the socio-political and economic conditions necessary to underpin those increases in productivity, we consider that it would be imprudent to follow strategies that might reduce agricultural productivity in the developed world and, furthermore, it would be prudent to increase productivity where this can be done with a minimal impact on GHG emissions.

This work supports the argument that intensive agriculture can help mitigate GHG emissions (Burnley et al 2010, Carlton et al. 2010). Lin et al. (2011) argue that empirical evidence suggests that an increase in deforestation is associated with increasing agricultural intensity. While this may apply in some developing countries, it is more likely to reflect socio-economic factors rather than agronomic ones. In the UK and the European Union the area under forest has increased since 1990 (when FAO forest area records start) and the area of crop land has decreased since 1961 (FAOSTAT 2012), indicating that intensive agriculture can be associated with reforestation and a reduction in cropland during a period of increasing production.

This work indicates that a regional approach to GHG emissions management may be most sensible, with reduced tillage used to complement conventional systems in regions where crop production is more intensive, and integrated production used where appropriate if further research confirms a GHG emissions advantage. There is no reason why the systems could not be combined, provided that disease and weed control does not become a limiting factor. Such a combination of systems can help UK agriculture to contribute to global food security not only by decreasing GHG emissions to mitigate climate change but also by increasing crop production to alleviate food insecurity in those regions of the world where crop production is threatened most by both diseases and climate change (Garrett et al. 2006; Stern 2007, Beddington 2010).

\section{Acknowledgements}


This research was funded by Carlton Consultancy and the Biotechnology and Biological Sciences Research Council (BBSRC) Bioenergy and Climate Change ISPG to Rothamsted Research and by the CLIMDIS Sustainable Arable LINK project consortium (supported by the Department for Environment, Food and Rural Affairs (Defra), LINK project LK09111). We thank David Hughes for Figure 5, Pete Berry for input on soil nitrogen budgets and Guy Leversha for input on reduced tillage cultivation and the anonymous referees for comments. We also thank Karen Garrett, Piet Boonekamp, Harald Scherm, Sukumar Chakraborty and Kees Booij and other colleagues who attended the international conference at Evora, Portugal on 'climate change and plant disease management' for discussions that contributed ideas to this paper. 


\section{References}

Anonymous (2009a). 1.02 billion people hungry; one sixth of humanity undernourished - more than ever before. FAO (Food and Agriculture Organisation of the United Nations). http://www.fao.org/news/story/en/item/20568/icode/.

Anonymous (2009b). Environmental Assessment Tool for Biomaterials. http://www.nnfcc.co.uk/chemicals-materials/our-services/lca-of-chemicals-andmaterials/environmental-assessment-tool-for-biomaterials

Azeez, G. (2009). Soil Carbon and Organic Farming. Soil Association, Bristol, UK

Badgley, C. Moghtader, J., Quintero, E., Zakem, E., Chappell, M.J., Avilés-Vázquez, K., Samulon, A. \& Perfecto, I. (2007) Organic agriculture and the global food supply. Renewable Agriculture and Food Systems 22, 86-108.

Barnes, A.P., Wreford, A., Butterworth, M.H., Semenov, M.A., Moran, D., Evans, N. \& Fitt BDL (2010). Adaptation to increasing severity of phoma stem canker on winter oilseed rape in the UK under climate change. Journal of Agricultural Science 148, 683-694.

Beddington, J. (2010). Food security: contributions from science to a new and greener revolution. Philosophical Transactions of the Royal Society B 365, 61-71.

Berry, P., Sylvester-Bradley, R., Philipps, L., Hatch, D., Cuttle, S., Rayns, F. \& Gosling, P. (2002). Is the productivity of organic farms restricted by the supply of available nitrogen? Soil Use and Management, 18 248-255. doi: 10.1111/j.1475-2743.2002.tb00266.x

Berry, P.M., Kindred, D.R. \& Paveley, N.D. (2008). Quantifying the effects of fungicides and disease resistance on greenhouse gas emissions associated with wheat production. Plant Pathology 57:1000-1008.

Berry, P.M., Kindred, D.R., Olesen, J.E., Jorgensen, L.N. \& Paveley, N.D. (2010). Quantifying the effect of interactions between disease control, nitrogen supply and land use change on the greenhouse gas emissions associated with wheat production. Plant Pathology 59, 753-763.

Betru S. \& Kawashima, H. (2010). African cereal demand and supply analysis: Past trends and future prospect African Journal of Agricultural Research Vol. 5(20), pp. 2757-2769. http://www.academicjournals.org/AJAR

Boonekamp, P. (2011). Plant diseases ignored in climate change debate. Public Service Review: European Science and Technology 10 (in press) 
Brisson, N., Gate, P., Gouache, D., Charmet, G., Oury, F. \& Huard, F. (2010). Why are wheat yields stagnating in Europe? A comprehensive data analysis for France. Field Crop Research 119, 201-212.

Bruisma, J. (2009). The resource outlook to 2050. By how much do land, water use and crop yields need to increase by 2050? Presented at: How to feed the world in 2050, FAO, Rome, Italy. ftp://ftp.fao.org/docrep/fao/012/ak971e/ak971e00.pdf

Burney, J.A., Davis, S.J. \& Lobell, D.B. (2010). Greenhouse gas mitigation by agricultural intensification. Proceedings of the National Academy of Science 26 12052-12057

Butterworth, M.H., Semenov, M.A., Barnes, A., Moran, D., West, J.S. \& Fitt, B.D.L. (2010). North-south divide; contrasting impacts of climate change on crop yields in Scotland and England. Journal of the Royal Society Interface 7, 123130.

Carlton, R., Berry, P. \& Smith, P. (2010). Impact of crop yield reduction on greenhouse gas emissions from compensatory cultivation of pasture and forested land. International Journal of Agricultural Sustainability, 8, 164-175

Chappell, M.J. \& LaValle, L.A. (2011). Food security and biodiversity: can we have both? An agroecological analysis Agriculture and Human values 28, 3-26. DOI: 10.1007/S10460-10009-19251-10464.

Committee on Climate Change (2010). Meeting Carbon Budgets - ensuring a lowcarbon recovery. $2^{\text {nd }}$ Progress report to parliament. Internet link: http://downloads.theccc.org.uk/0610/pr meeting carbon budgets full report. pdf

DECC (2010). Agriculture GHG inventory summary factsheet. Department of Energy and Climate Change, UK.

DECC (2011). UK emissions statistics 2009 final UK figures. Department of Energy and Climate Change, UK. Internety link:

http://www.decc.gov.uk/en/content/cms/statistics/climate change/gg emission s/uk emissions/2009 final/2009 final.aspx

DEFRA (2005). British survey of fertiliser practice. 2004. Department of Environment, Food and Rural Affairs, UK. Internet link: http://www.defra.gov.uk/statistics/foodfarm/enviro/fertiliserpractice/

DEFRA (2006). British survey of fertiliser practice. 2005. Department of Environment, Food and Rural Affairs, UK. Internet link: http://www.defra.gov.uk/statistics/foodfarm/enviro/fertiliserpractice/ 
DEFRA (2007). British survey of fertiliser practice. 2006. Department of Environment, Food and Rural Affairs, UK. Internet link: http://www.defra.gov.uk/statistics/foodfarm/enviro/fertiliserpractice/

DEFRA (2008). British survey of fertiliser practice. 2007. Department of Environment, Food and Rural Affairs, UK. Internet link: http://www.defra.gov.uk/statistics/foodfarm/enviro/fertiliserpractice/

DEFRA (2009a). British survey of fertiliser practice. 2008. Department of Environment, Food and Rural Affairs, UK. Internet link: http://www.defra.gov.uk/statistics/foodfarm/enviro/fertiliserpractice/

DEFRA (2009b). Agriculture in the United Kingdom 2009. Department of Environment, Food and Rural Affairs, UK. Internet link: http://www.defra.gov.uk/statistics/files/defra-stats-auk-2009.pdf

De Klein C., Novoa R.S.A., Ogle S., Smith K. A., Rochette P., Wirth T. C., McConkey B.G., Walsh M., Mosier A., Rypdal K. \& Williams S.A. (2006). $\mathrm{N}_{2} \mathrm{O}$ emissions from managed soils, and $\mathrm{CO}_{2}$ emissions from lime and urea application. In: Eggleston H.S., Buendia L., Miwa K., Ngara T., Tanabe K. (eds): 2006 IPCC Guidelines for National Greenhouse Gas Inventories, National Greenhouse Gas Inventories Programme, IGES, Japan: 11.11. Internet page: http://www.ipccnggip.iges.or.jp/public/2006gl/pdf/4_Volume4/V4_11_Ch11_N2O\&CO2.pdf

Evans, N., Baierl, A., Semenov, M.A., Gladders, P. \& Fitt, B.D.L. (2008). Range and severity of a plant disease increased by global warming. Journal of the Royal Society Interface. 5: 525-531

FAO (2002). World Agriculture Towards 2015/2030. Summary Report. Food and Agriculture Organisation of the United Nations, Rome, Italy. 97 pp. ftp://ftp.fao.org/docrep/fao/004/y3557e/y3557e.pdf

FAO (2006). Livestock's Long Shadow. Environmental Issues and Options. Food and Agriculture Organisation of the United Nations, Rome, Italy. 390 pp. ftp://ftp.fao.org/docrep/fao/010/a0701e/a0701e.pdf

FAOSTAT (2012). Resourcestat, Food and Agriculture Organisation of the United Nations, Rome, Italy. http://faostat.fao.org/site/377/default.aspx\#ancor

Fitt, B.D.L., Huang, Y.J., van den Bosch, F. \& West, J.S. (2006). Coexistence of related pathogen species on arable crops in space and time. Annual Review of Phytopathology 44: 163-182.

Fitt, B.D.L., Fraaije, B.A., Chandramohan, P. \& Shaw, M.W. (2011). Impacts of changing air composition on severity of arable crop disease epidemics. Plant Pathology 60, 44-53. 
Garrett, K.A., Dendy, S.P., Frank, E.E., Rouse, M.N. \& Travers, S.E. (2006). Climate change effects on plant disease: genomes to ecosystems. Annual Review of Phytopathology 44: 489-509.

Garthwaite, D.G., Thomas, M.R., Parrish, G., Smith, L. \& Barker, I. (2010a). Pesticide Usage Survey Report 224. Arable Crops in Great Britain 2008. Department of Food, Environment and Rural Affairs, UK.

Garthwaite, D.G., Barker, I., Parrish, G., Smith, L. \& Chippindale, C. (2010b). Pesticide Usage Survey Report 232. Grassland and Fodder Crops in Great Britain 2009. Department of Food, Environment and Rural Affairs, UK.

Glendining, M.J., Dailey, A.G., Williams, A.G., van Evert, F.K., Goulding, K.W.T. \& Whitmore, A.P. (2009). Is it possible to increase the sustainability of arable and ruminant agriculture by reducing inputs? Agricultural Systems 99:117-125.

Gregory, .PJ., Johnson, S.N., Newton, A.C. \& Ingram. J.S. (2009). Integrating pests and pathogens into the climate change/food security debate. Journal of Experimental Botany 60, 2827-38.

Guo, L.B. \& Gifford, R.M. (2002). Soil carbon stocks and land use change: a meta analysis. Global Change Biology 8: 345-359.

Halberg, N., Sulser,T.B., Hogh-Jensen, H., Rosegrant, M.W. \& Knudsen, M.T. (2006). The impact of organic farming on food security in a regional and global perspectiv. in Global Development of Organic Agriculture: Challenges and Prospects, 277-322. Edited by N Halberg, H F Alroe, M T Knudsen and E S Kristensen CABI March 2006

Hughes, D.J., West, J.S., Atkins, S.D., Gladders, P, Jeger, M.J. \& Fitt, B.D.L. (2011). Effects of disease control by fungicides on Greenhouse Gas (GHG) emissions by UK arable crop production. Pest Management Science (in press)

IPCC (2002). Climate Change and Biodiversity. Technical Paper V. H Gitay, A Suárez, RT.Watson, DJ Dokken (Eds). IPCC, Geneva, Switzerland. pp 85. http://www.ipcc.ch/pdf/technical-papers/climate-changes-biodiversity-en.pdf

Jackson, J., Li, Y., Passant, N., Thistlethwaite, G., Thomson, A. \& Cardenas, L. (2007). Greenhouse Gas Inventories for England, Scotland, Wales and Northern Ireland: 1990-2005. Didcot, UK, AEA Environment and Technology, 40 pp. (http://nora.nerc.ac.uk/2230/)

Jones, P. \& Crane, R. (2008). England and Wales under organic agriculture: how much food could be produced? Centre for agricultural strategy, University of Reading, UK. 
Kirchmann, H., Bergstrom, L., Katterer, T., Mattsson, L. \& Gessein, S. (2007). Comparison of long-term organic and conventional crop-livestock systems on a previously nutrient-depleted soil in Sweden. Agronomy Journal 99 960-972

Lal, R. (2004). Soil carbon sequestration impacts on global climate change and food security. Science 304, 1623-1627.

Lampkin,N., Measures, M. \& Padel, S. (2008). 2009 Organic Farm Management Handbook. Aberystwyth University, Ceredigion, UK.

Lin, B. B., Chappell, M. J., Vandermeer, J., Smith, G., Quintero, E., Bezner-Kerr, R., Griffith, D. M., Ketcham, S., Latta, S. C., McMichael, P., McGuire, K. L., Nigh, R., Rocheleau, D., Soluri, J., Perfecto, I. (2011). Effects of industrial agriculture on climate change and the mitigation potential of small-scale agroecological farms. CAB Reviews: Perspectives in Agriculture, Veterinary Science, Nutrition and Natural Resources 6, 1-18.

Lobell, D.B., Schlenker, W. \& Costa-Roberts, J. (2011). Climate Trends and Global Crop Production Since 1980. Science 333, 616-620.

Low,A.J. (1973). Soil Structure and Crop Yield. Journal of Soil Science, 24, 249-259. doi: 10.1111/j.1365-2389.1973.tb00762.x

Mahmuti, M., West, J.S., Watts, J., Gladders, P. \& Fitt, B.D.L. (2009). Controlling crop disease contributes to both food security and climate change mitigation. International Journal of Agricultural Sustainability 7, 189-202.

Oerke, E.C. (2006). Crop losses to pests. Journal of Agricultural Science 144:31-43.

Petersen, J., Haastrup, M., Knudsen, L. \& Olesen, J.E. (2010). Causes of yield stagnation in winter wheat in Denmark. DJF Report Plant Science 147, 121 138.

PSD (2009) Proposal for a regulation of the European Parliament and of the Council concerning the placing of plant protection products on the market. Summary Impact Assessment. Health and Safety Executive Chemical Regulation Directorate. Internet link: http://www.pesticides.gov.uk/uploadedfiles/Web Assets/PSD/Outcomes pape $r$ - summary impact assessment (Jan 09).pdf

Rayns, F., Rosenfeld, A., Schmutz, U. \& Rahn, C. (2009). A comparison of two models to predict nitrogen dynamics in organic agricultural systems. Aspects of Applied Biology 93: 219-222.

Rosegrant, M.W., Leach N. \& Gerpacio R. V. (1999) Alternative futures for world cereal and meat consumption. Proceedings of the Nutrition Society 58, 219234. DOI: $10.1017 /$ S0029665199000312. 
Schmidhuber, J. \& Tubiello, F.N. (2007). Global food security under climate change. Proceedings of the National Academy of Science of the United States of America 104:19703-19708.

Smith, P. (2008). Land use change and soil organic carbon dynamics. Nutrient Cycling in Agroecosystems 81: 169-178.

Smith, P., Powlson, D.S., Glendining, M.J. \& Smith, J.U. (1998). Preliminary estimates of the potential for carbon mitigation in European soils through no-till farming. Global Change Biology 4: 679-685.

Smith, P., Goulding, K.W., Smith, K.A., Powlson, D.S., Smith, J.U., Falloon, P.D. \& Coleman, K. (2001). Enhancing the carbon sink in European agricultural soils: Including trace gas fluxes in estimates of carbon mitigation potential. Nutrient Cycling in Agroecosystems 60: 237-252.

Smith, P., Martino, D., Cai, Z., Gwary, D., Janzen, H., Kumar, P., McCarl, B., Ogle, S., O'Mara, F., Rice, C., Scholes, B., Sirotenko, O., Howden, M., McAllister, T., Pan, G., Romanenkov, V., Schneider, U., Towprayoon, S., Wattenbach, M. \& Smith, J. (2008). Greenhouse gas mitigation options in agriculture. Philosophical Transactions of the Royal Society B 363:789-813.

Smith, P., Bhogal, A., Edgington, P., Black, H., Lilly, A., Barraclough, D., Worrall, F., Hillier, J. \& Merrington, G. (2010). Consequences of feasible future agricultural land use change on soil organic carbon stocks and greenhouse gas emissions in Great Britain. Soil Use and Management 26, 381-398. doi: 10.1111/j.14752743.2010.00283.x.et al. 2010

Smyth, S.J., Gusta, M., Belcher, K., Phillips, P.W.B. \& Castle, D. (2011). Environmental impacts from herbicide tolerant canola production in Western Canada. Agricultural Systems 104, 403-410. doi:10.1016/j.agsy.2011.01.004.

Stern, N. (2007). The economics of climate change: the Stern review. Cambridge, UK: Cambridge University Press. 692 pp.

West, J.S., Kharbanda, P., Barbetti, M.J. \& Fitt, B.D.L. (2001). Epidemiology and management of Leptosphaeria maculans (phoma stem canker) in Australia, Canada and Europe. Plant Pathology 50, 10-27.

West J.S., Fitt B.D.L. (2005) Population dynamics and dispersal of Leptosphaeria maculans (blackleg of canola). Australasian Plant Pathology 34: 457-461.

West, J.S., Townsend, J.A., Stevens, M., Fitt, B.D.L. (2012a). Comparative biology of different plant pathogens to estimate effects of climate change on crop diseases in Europe. European Journal of Plant Pathology (this issue) 
West JS, Holdgate S, Townsend JA, Edwards SG, Jennings P, Fitt BDL. (2012b). Impacts of changing climate and agronomic factors on fusarium ear blight of wheat in the UK. Fungal Ecology 5: 53-61.

WHO (2011). Gender, Climate Change and Health. World Health Organisation, Geneva, Switzerland, 38 pp.

Williams, A.G., Audsley, E. \& Sandars, D.L. (2006). Final report to Defra on project IS0205: Determining the environmental burdens and resource use in the production of agricultural and horticultural commodities. London: Defra.

UKCP (2009). United Kingdom climate projections. Internet link: http://ukclimateprojections.defra.gov.uk/content/view/1477/499/

UN (2011). World Population Prospects Economic \& Social Affairs. The 2010 Revision. Highlights and Advanced Tables. United Nations, New York, USA. 142 pp. http://esa.un.org/wpp/Documentation/pdf/WPP2010 Highlights.pdf 


\section{Figure legends}

Figure 1 The components of GHG emissions for UK crop production under conventional (a), integrated (b) and organic (c) agricultural systems. The size of each pie chart represents the size of emissions under each system. The reduced tillage system is omitted as the SOC change represents a net sequestration and it is not possible to illustrate this on a pie chart

Figure 2 UK GHG emissions for conventional, reduced tillage, organic and integrated agricultural systems required to maintain current five year average crop production

Figure 3 East of England GHG emissions for conventional, reduced tillage, organic and integrated agricultural systems required to maintain current (five year average) crop production

Figure 4 North West region GHG emissions for conventional, reduced tillage, organic and integrated agricultural systems required to maintain current (five year average) crop production

Figure 5. Estimated decrease in $\mathrm{GHG}$ emissions ( $\mathrm{Mt} \mathrm{CO}_{2}-\mathrm{e}$.) through use of fungicides to control

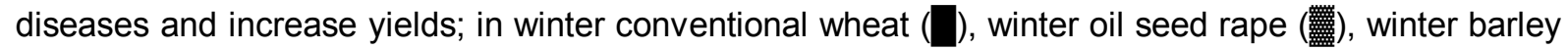

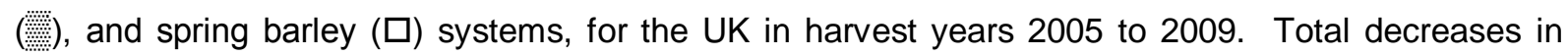
GHG emissions are 15\% (2005), 14\% (2006), 15\% (2007), 14\% (2008), 13\% (2009) of the estimated total GHG emissions ( $\mathrm{Mt} \mathrm{CO}_{2}$ eq.) if these four crops were grown without fungicide treatment. Results for winter wheat are based on Berry et al. (2008) Results for winter oilseed rape are based on Mahmuti et al. (2009). Adapted from Hughes et al. (2011). 
Figure 1

1

2
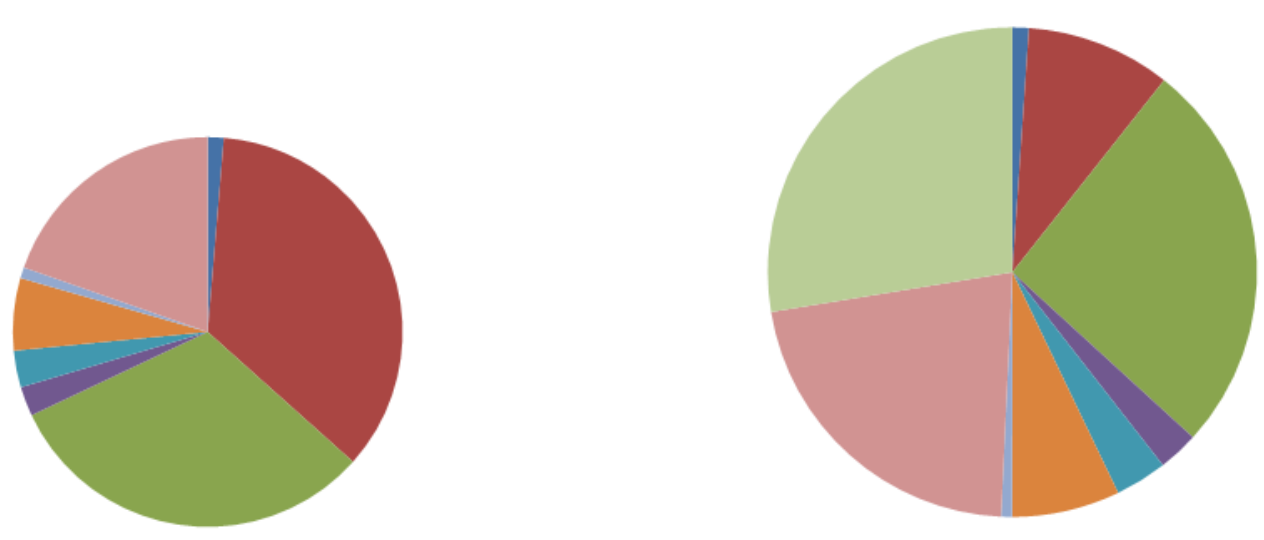

- Seed

n fertiliser production

- Soil N2O emissions

- P fertiliser (P2O5)

- K fertiliser (K2O)

- Lime (production and $\mathrm{CO} 2$ )

- Crop protection products

- Operation costs (equipment and fuel)

SOC changes 
Figure 2

1

2

3

4

5

6

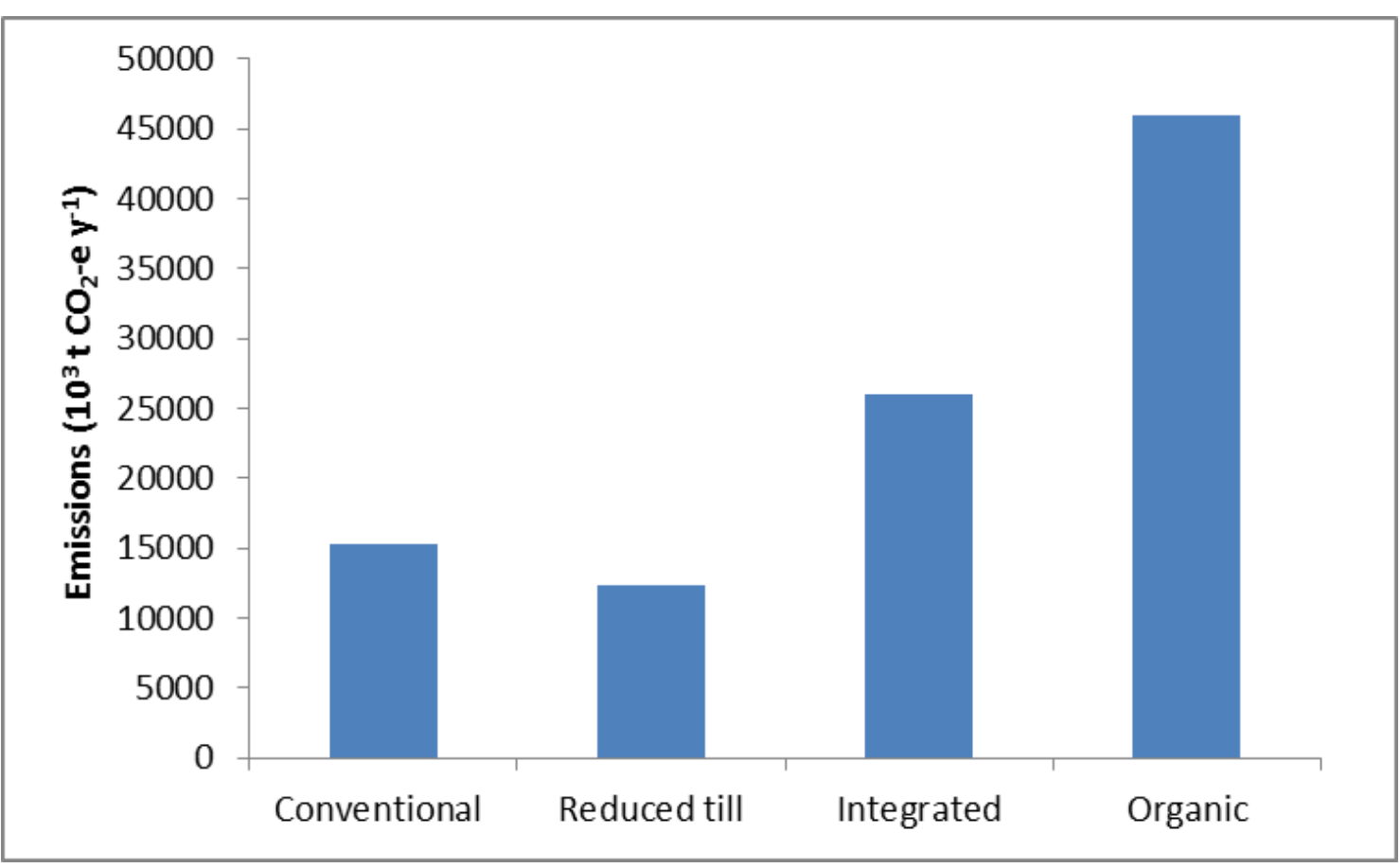


Figure 3

1

2

3

4

5

6

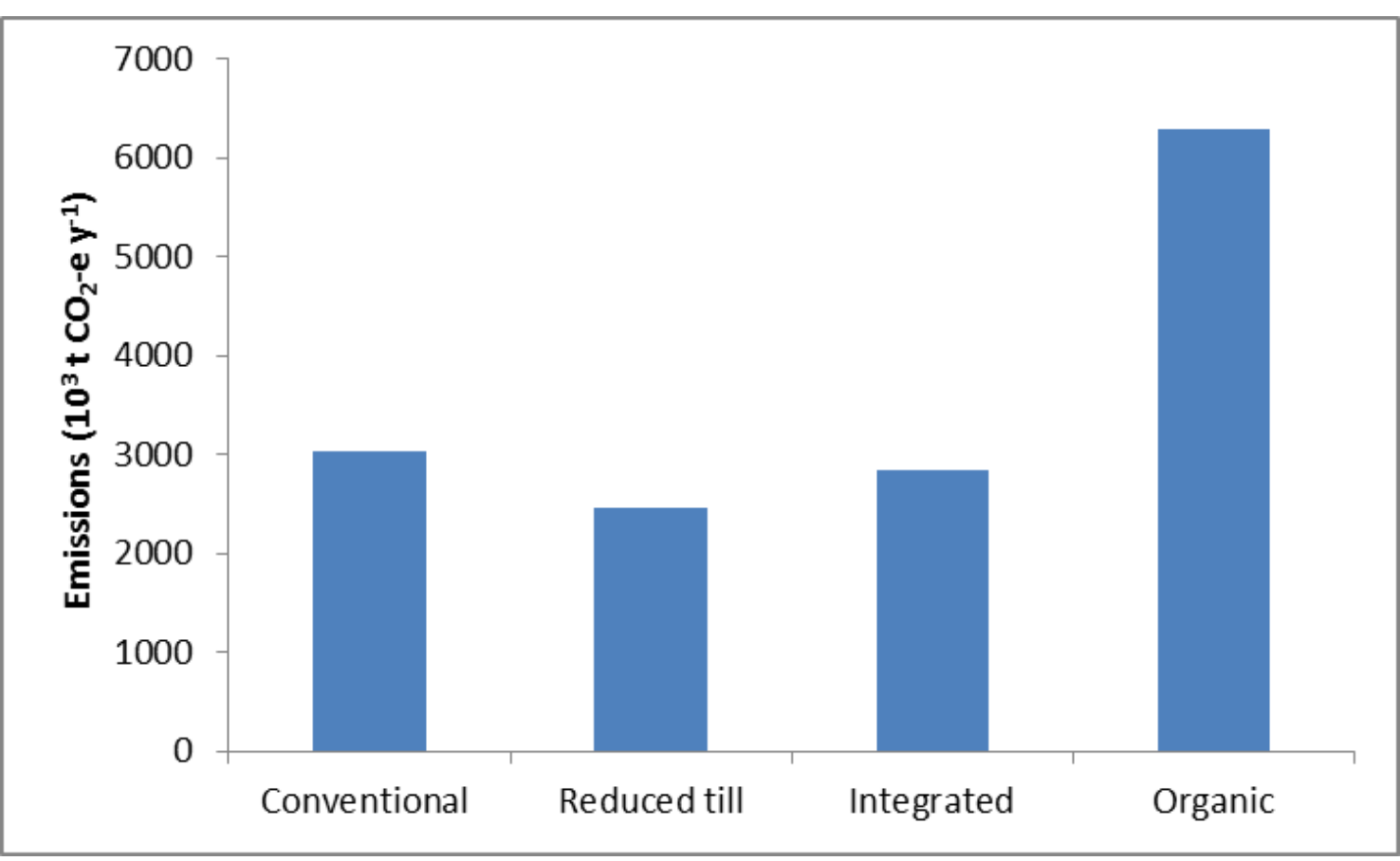


Figure 4

1

2

3

4

5

6

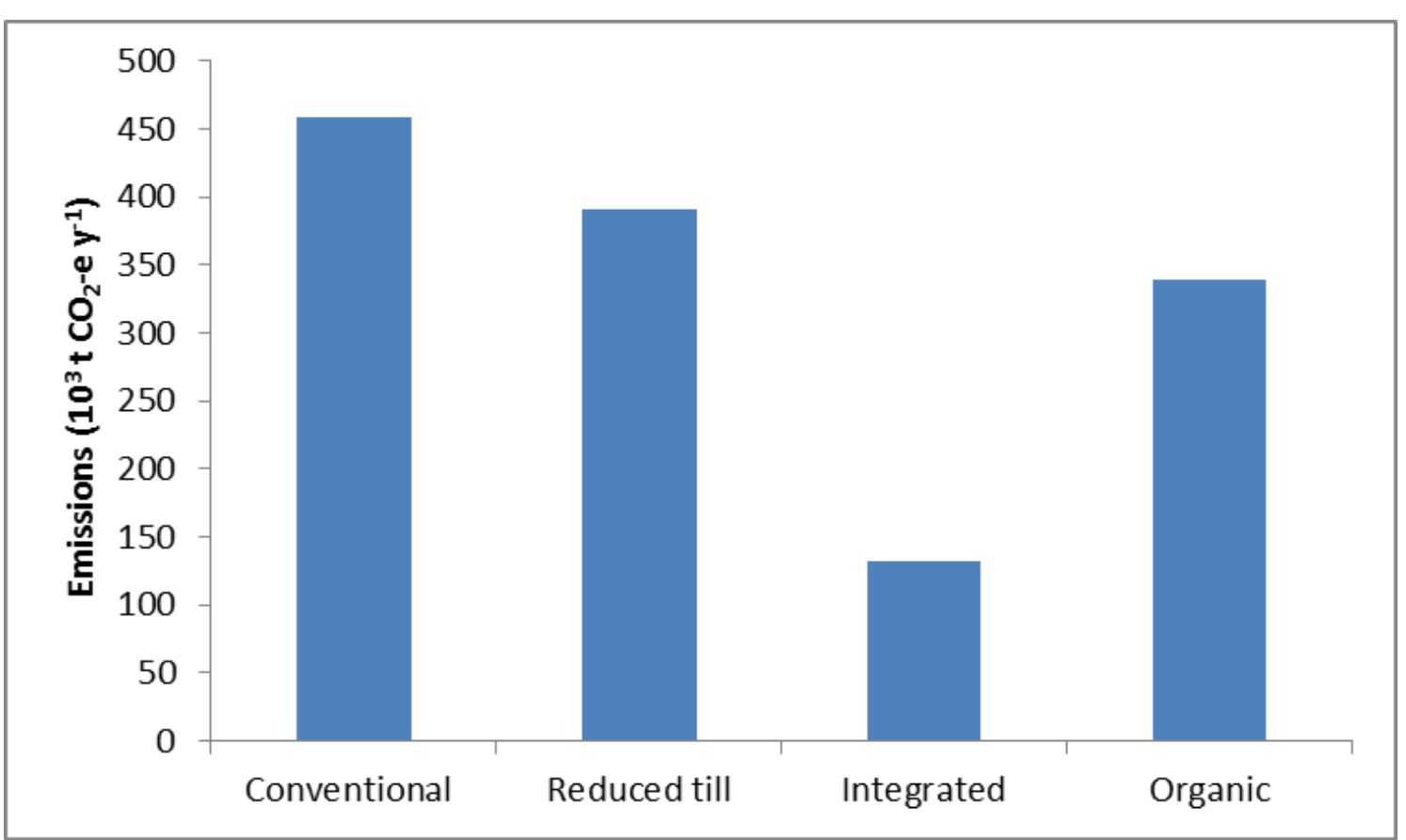


Figure 5

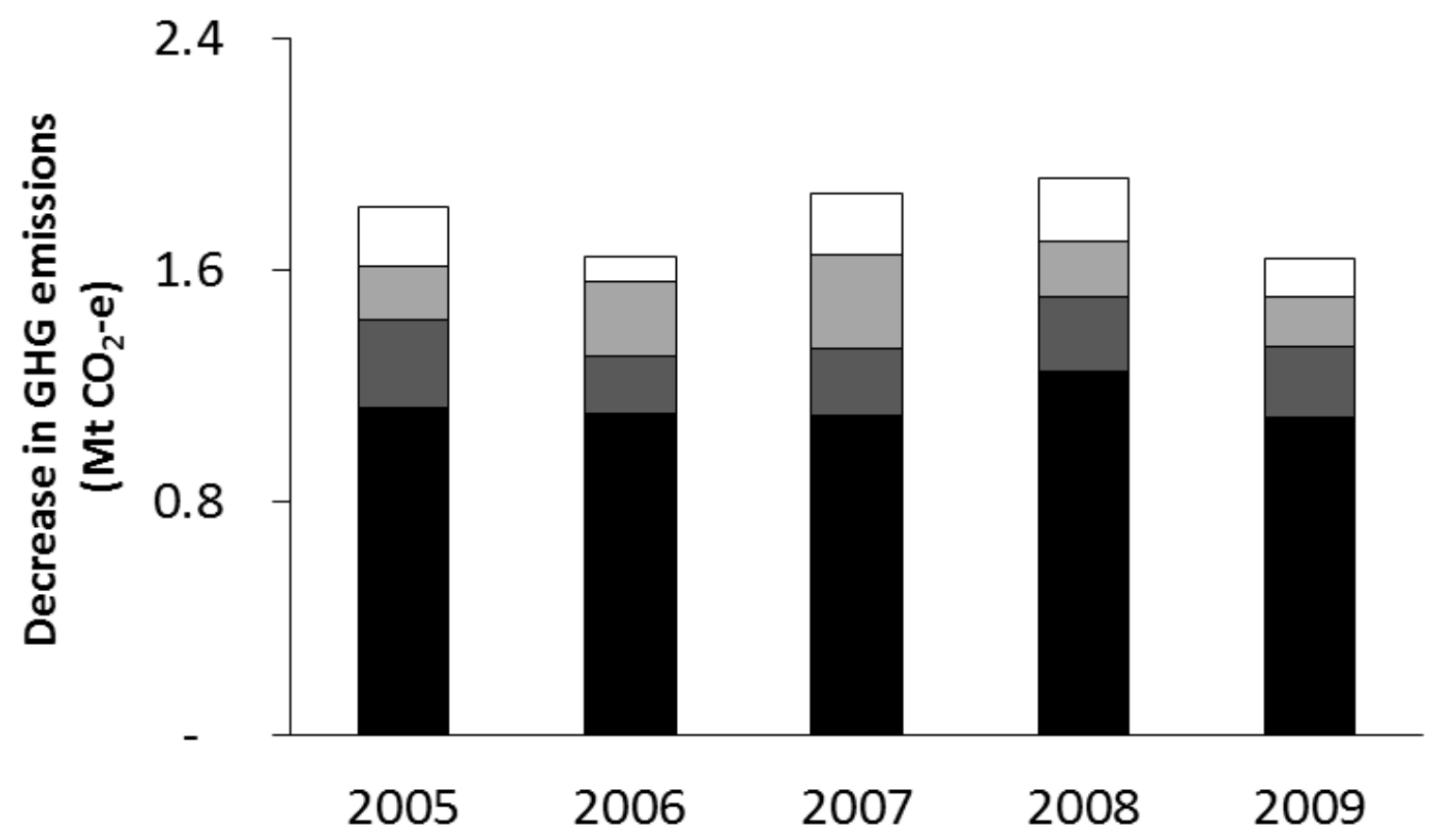

27

28

29

30

31

32

33

34

35

36

37

38

39

40

41

42

43

44

45

46

47

48

49

50

51

52

53

54

55

56

57

58

59

60

61

62 
Table 1 Changes in $\mathrm{SOC}^{\mathrm{a}}$ associated with changes in management practices associated with different arable crop systems in the UK to maintain current (5-year mean) total crop production.

\begin{tabular}{lcl}
\hline Practice & $\begin{array}{c}\text { SOC change factor } \\
\left(\mathrm{t} \mathrm{C} \mathrm{ha} \mathrm{y}^{-1}\right)\end{array}$ & References \\
\hline Conversion of pasture to arable (LUC) & -2.36 & Carlton et al. 2010 \\
Organic \& integrated sequestration (S) & 0.56 & Azeez 2009 \\
LUC $+\mathrm{S}$ & -1.8 & Carlton et al. 2010, Azeez 2009 \\
Reduced tillage & 0.14 & Smith et al. 2008 \\
\hline
\end{tabular}

a SOC: soil organic carbon; LUC: Land use change - conversion of pasture to arable land; S: organic and integrated sequestration 
Table 2 Area of arable land needed to maintain current UK five year average crop production under conventional, reduced tillage, organic and integrated agricultural systems, including organic/conventional yield ratios

\begin{tabular}{|c|c|c|c|c|}
\hline Crop & $\begin{array}{l}\text { Conventional } \\
\text { (= reduced till) } \\
\text { UK average } \\
\text { area }^{\mathrm{a}} \text { (000 ha) }\end{array}$ & $\begin{array}{l}\text { Integrated area } \\
\text { assuming } 50 \% \\
\text { fertility enhancing } \\
\text { area (000 ha) }\end{array}$ & $\begin{array}{c}\text { Organic/ } \\
\text { conventional } \\
\text { yield ratio }\end{array}$ & $\begin{array}{c}\text { Organic area } \\
\text { assuming } 50 \% \\
\text { fertility enhancing } \\
\text { area }^{\mathrm{b}} \text { (000 ha) }\end{array}$ \\
\hline Wheat & 1882 & 1882 & 0.68 & 2784 \\
\hline Barley & 982 & 982 & 0.74 & 1334 \\
\hline Oats & 122 & 122 & 0.42 & 288 \\
\hline Oilseed rape & 606 & 606 & 0.70 & 865 \\
\hline Potatoes & 142 & 142 & 0.77 & 185 \\
\hline Sugar beet & 128 & 128 & 0.83 & 183 \\
\hline Peas and beans & 202 & 202 & 0.83 & 229 \\
\hline Other crops & 310 & 310 & 0.83 & 443 \\
\hline Grass/clover ${ }^{c}$ & 1182 & 4374 & & 6311 \\
\hline Uncropped & 482 & 0 & & 0 \\
\hline Total arable area & 6038 & 8748 & & 12622 \\
\hline
\end{tabular}


Table 3 Annual GHG emissions associated with UK crop production per hectare under selected agricultural systems (SOC changes are not included)

\begin{tabular}{|c|c|c|c|c|}
\hline \multirow[b]{2}{*}{ Crop } & \multicolumn{4}{|c|}{ Emissions $\left(\mathrm{kg} \mathrm{CO}_{2} \mathrm{ha}^{-1}\right)$} \\
\hline & Conventional & Reduced till & Integrated & Organic \\
\hline Wheat & 3616 & 3563 & 3051 & 1879 \\
\hline Barley & 2717 & 2564 & 2147 & 1875 \\
\hline Oats & 2747 & 2594 & 2182 & 1824 \\
\hline Oilseed rape & 3484 & 3326 & 2920 & 1656 \\
\hline Potatoes & 3634 & 3634 & 3070 & 2307 \\
\hline Sugar beet & 3076 & 3076 & 2548 & 2154 \\
\hline Peas and beans & 666 & 513 & 659 & 935 \\
\hline Other crops & 1427 & 1427 & 1216 & 1390 \\
\hline Grass/clover & 1901 & 1801 & 732 & 948 \\
\hline
\end{tabular}


Table 4 The GHG emissions for UK wide crop production under selected agricultural systems showing emissions associated crop production and emissions associated with $\mathrm{SOC}$ changes

\begin{tabular}{lcccc}
\hline Source of emissions & & \multicolumn{3}{c}{ Emissions $\left(000 \mathrm{t} \mathrm{CO}_{2} \mathrm{ha}^{-1}\right)$} \\
& Conventional & Reduced till & Integrated & Organic \\
\hline Crop & 15653 & 15139 & 14361 & 17323 \\
$\begin{array}{l}\text { SOC sequestration on } \\
\text { long term arable land }\end{array}$ & 0 & -1904 & -12378 & -12378 \\
$\begin{array}{l}\text { SOC depletion from } \\
\text { converted pasture }\end{array}$ & 0 & 0 & 17854 & 43371 \\
Total (crop plus SOC) & 15653 & 13236 & 19837 & 48315 \\
\hline
\end{tabular}


Table 5 Area of arable land needed to meet East of England region five year average crop production under selected agricultural systems

\begin{tabular}{lcccc}
\hline Crop & $\begin{array}{c}\text { Conventional } \\
(=\text { reduced till) } \\
\text { average area }^{\mathrm{a}} \\
(000 \mathrm{ha})\end{array}$ & $\begin{array}{c}\text { Integrated area } \\
\text { assuming } 25 \% \\
\text { fertility enhancing } \\
\text { area (000 ha) }\end{array}$ & $\begin{array}{c}\text { Conventional: } \\
\text { organic yield } \\
\text { ratio }\end{array}$ & $\begin{array}{c}\text { Organic area } \\
\text { assuming 25\% } \\
\text { fertility enhancing } \\
\text { area }^{\text {b }} \text { (000 ha) }\end{array}$ \\
\hline Wheat & 492 & 492 & 0.72 & 681 \\
Barley & 136 & 136 & 0.49 & 277 \\
Oats & 10 & 10 & 0.41 & 23 \\
Oilseed rape & 121 & 121 & 0.70 & 173 \\
Potatoes & 35 & 35 & 0.83 & 42 \\
Sugar beet & 75 & 75 & 0.83 & 107 \\
Peas and beans & 58 & 58 & 0.83 & 70 \\
Other crops & 31 & 31 & 0.83 & 45 \\
Grass/clover & 32 & 319 & & 472 \\
Uncropped & 34 & 0 & & 0 \\
Total & 1024 & 1278 & 1890 \\
\hline The areas under the conventional system are taken from DEFRA statistics (DEFRA 2009b). ${ }^{\mathrm{b}}$ The \\
area under each crop (excepting grass/clover) is calculated by dividing the equivalent conventional \\
area by the yield ratio. ${ }^{\mathrm{c}}$ The areas under grass/clover for the integrated and organic sytems are 25\% \\
of the total arable area
\end{tabular}


Table 6 Area of arable land needed to meet North West region five year average crop production under selected agricultural systems

\begin{tabular}{|c|c|c|c|c|}
\hline Crop & $\begin{array}{c}\text { Conventional } \\
\text { (= reduced till) } \\
\text { UK } 5 \mathrm{yr} \\
\text { average area } \\
\text { (000 ha) }\end{array}$ & $\begin{array}{l}\text { Integrated area } \\
\text { assuming } 50 \% \\
\text { fertility enhancing } \\
\text { area (000 ha) }\end{array}$ & $\begin{array}{c}\text { Conventional: } \\
\text { organic yield } \\
\text { ratio }\end{array}$ & $\begin{array}{c}\text { Organic area } \\
\text { assuming } 50 \% \\
\text { fertility enhancing } \\
\text { area }^{b}(000 \mathrm{ha})\end{array}$ \\
\hline Wheat & 32 & 32 & 0.79 & 41 \\
\hline Barley & 37 & 37 & 0.95 & 40 \\
\hline Oats & 5 & 5 & 0.63 & 8 \\
\hline Oilseed rape & 4 & 4 & 0.70 & 6 \\
\hline Potatoes & 7 & 7 & 0.77 & 10 \\
\hline Sugar beet & 0 & 0 & 0.83 & 0 \\
\hline Peas and beans & 2 & 2 & 0.83 & 2 \\
\hline Other crops & 17 & 17 & 0.83 & 24 \\
\hline Grass/clover ${ }^{\mathrm{c}}$ & 86 & 105 & & 130 \\
\hline Uncropped & 8 & 0 & & 0 \\
\hline Total & 199 & 210 & & 261 \\
\hline
\end{tabular}




\section{Appendix 1}

Table A1. Inputs used for carbon footprint calculations. In the System column $\mathrm{C}=$ conventional, $\mathrm{RT}=$ reduced tillage, $\mathrm{O}=$ organic and $\mathrm{I}=$ integrated. Fertiliser and lime inputs for conventional and reduced tillage systems are averages of UK usage data for $2004-8$ except oats, peas and beans, other field crops and grass where single year (2008) data are used (DEFRA 2005, 2006, 2007, 2008, 2009a). Under integrated production P and K applications to soils are identical to conventional, lime application rates are identical to organic and $\mathrm{N}$ from fertility building is augmented by inorganic $\mathrm{N}$ applications to match overall conventional application levels. Pesticide inputs are based on 2008 data for cash crops (Garthwaite 2010 ) and 2009 data for grass (Garthwaite 2010b). Organic system inputs of $\mathrm{P}, \mathrm{K}$ and lime are based on data from Lampkin et al. (2008). Average peak $\mathrm{N}$ availability in organic systems is assumed to be $100 \mathrm{~kg} \mathrm{~N} \mathrm{ha}^{-1}$ during cropping based on data from Rayns et al. 2009. Annual applications of FYM to grass are assumed to add $14 \mathrm{t}$ available $\mathrm{N}$ ha ${ }^{-1}$ (Berry et al. 2002). As data on the carbon cost of organic pesticides is unavailable it is assumed that organic systems avoid all use of pesticides. It is assumed that no $\mathrm{K}$ specific $\left(\mathrm{K}_{2} \mathrm{O}\right)$ applications are made to organic systems (i.e. $\mathrm{K}$ requirements are met through application of organic manures and weathering of soils). No costs are allocated to sulphur, molluscicides or seed treatments as these account for less than $1 \mathrm{~kg} \mathrm{CO}_{2}$ ha ${ }^{-1}$ in all cases. No costs are allocated to sulphuric acid as the UK authorisation for agricultural applications was withdrawn in 2010. Operation energy requirements are based on Williams et al. 2006 


\begin{tabular}{|c|c|c|c|c|c|c|c|c|c|c|c|c|c|}
\hline \multirow[b]{2}{*}{ Crop } & \multirow[b]{2}{*}{ System } & \multirow[b]{2}{*}{ Seed } & \multirow[b]{2}{*}{$\underset{N}{\text { Organic }}$} & \multirow[b]{2}{*}{ Inorganic N } & \multicolumn{5}{|c|}{ Inputs $\left(\mathrm{kg} \mathrm{ha}^{-1}\right)$} & \multirow[b]{2}{*}{ Fungicide } & \multicolumn{3}{|c|}{ Operations energy $\left(\mathrm{MJ} \mathrm{ha}^{-1}\right)$} \\
\hline & & & & & $\mathrm{P}$ & $\mathrm{K}$ & Lime & Herbicide & Insecticide & & PGR & Fuel & Equipment \\
\hline \multirow[t]{4}{*}{ Wheat } & $\mathrm{C}$ & 175 & 0 & 196 & 40 & 45 & 300 & 2.09 & 0.06 & 1.37 & 1.28 & 3615 & 1711 \\
\hline & $\mathrm{RT}$ & 175 & 0 & 196 & 40 & 45 & 300 & 3.14 & 0.06 & 1.37 & 1.28 & 2200 & 1290 \\
\hline & $\mathrm{O}$ & 200 & 100 & 0 & 71 & 0 & 714 & 0.00 & 0.00 & 0.00 & 0.00 & 3946 & 2296 \\
\hline & I & 175 & 100 & 96 & 40 & 45 & 714 & 2.09 & 0.06 & 1.37 & 1.28 & 4081 & 2505 \\
\hline \multirow[t]{4}{*}{ Barley } & C & 175 & 0 & 121 & 38 & 55 & 429 & 1.33 & 0.01 & 0.62 & 0.39 & 3615 & 1711 \\
\hline & $\mathrm{RT}$ & 175 & 0 & 121 & 38 & 55 & 429 & 2.00 & 0.01 & 0.62 & 0.39 & 2200 & 1290 \\
\hline & 0 & 190 & 100 & 0 & 71 & 0 & 714 & 0.00 & 0.00 & 0.00 & 0.00 & 3946 & 2296 \\
\hline & 1 & 175 & 100 & 21 & 38 & 55 & 714 & 1.33 & 0.01 & 0.62 & 0.39 & 4081 & 2505 \\
\hline \multirow[t]{4}{*}{ Oats } & $\mathrm{C}$ & 175 & 0 & 134 & 35 & 51 & 224 & 0.42 & 0.02 & 0.32 & 0.82 & 3615 & 1711 \\
\hline & $\mathrm{RT}$ & 175 & 0 & 134 & 35 & 51 & 224 & 0.63 & 0.02 & 0.32 & 0.82 & 2200 & 1290 \\
\hline & 0 & 200 & 100 & 0 & 71 & 0 & 714 & 0.00 & 0.00 & 0.00 & 0.00 & 3946 & 2296 \\
\hline & 1 & 175 & 100 & 34 & 35 & 51 & 714 & 0.42 & 0.02 & 0.32 & 0.82 & 4081 & 2505 \\
\hline \multirow[t]{4}{*}{ Oilseed rape } & C & 5 & 0 & 202 & 39 & 42 & 409 & 2.32 & 0.04 & 0.48 & 0.00 & 3538 & 1522 \\
\hline & $\mathrm{RT}$ & 5 & 0 & 202 & 39 & 42 & 409 & 3.48 & 0.04 & 0.48 & 0.00 & 2123 & 1101 \\
\hline & 0 & 5 & 100 & 0 & 71 & 0 & 714 & 0.00 & 0.00 & 0.00 & 0.00 & 3656 & 2079 \\
\hline & 1 & 5 & 100 & 102 & 39 & 42 & 714 & 2.32 & 0.04 & 0.48 & 0.00 & 4003 & 2316 \\
\hline \multirow[t]{3}{*}{ Potatoes } & C & 1000 & 0 & 149 & 132 & 218 & 0 & 2.30 & 1.35 & 8.10 & 0.54 & 8058 & 2475 \\
\hline & O & 2500 & 100 & 0 & 71 & 0 & 714 & 0.00 & 0.00 & 0.00 & 0.00 & 8196 & 3035 \\
\hline & I & 1000 & 100 & 49 & 132 & 218 & 714 & 2.30 & 1.35 & 8.10 & 0.54 & 8524 & 3268 \\
\hline \multirow[t]{3}{*}{ Sugar beet } & $\mathrm{C}$ & 100 & 0 & 95 & 36 & 104 & 1170 & 3.34 & 0.13 & 0.27 & 0.00 & 8058 & 2475 \\
\hline & $\mathrm{O}$ & 100 & 100 & 0 & 71 & 0 & 714 & 0.00 & 0.00 & 0.00 & 0.00 & 8196 & 3035 \\
\hline & 1 & 100 & 100 & 0 & 36 & 104 & 714 & 3.34 & 0.13 & 0.27 & 0.00 & 8524 & 3268 \\
\hline \multirow[t]{4}{*}{ Pea and beans } & $\mathrm{C}$ & 250 & 0 & 1 & 30 & 23 & 89 & 2.05 & 0.06 & 1.03 & 0.00 & 3475 & 1547 \\
\hline & $\mathrm{RT}$ & 250 & 0 & 1 & 30 & 23 & 89 & 4.10 & 0.06 & 1.03 & 0.00 & 2060 & 1125 \\
\hline & 0 & 250 & 0 & 0 & 71 & 0 & 714 & 0.00 & 0.00 & 0.00 & 0.00 & 3209 & 1330 \\
\hline & 1 & 250 & 0 & 1 & 30 & 23 & 714 & 2.05 & 0.06 & 1.03 & 0.00 & 3475 & 1547 \\
\hline \multirow[t]{3}{*}{ Other field crops } & $\mathrm{C}$ & 10 & 0 & 49 & 24 & 31 & 313 & 2.31 & 0.06 & 0.82 & 0.00 & 3615 & 1711 \\
\hline & $\mathrm{O}$ & 10 & 100 & 0 & 71 & 0 & 714 & 0.00 & 0.00 & 0.00 & 0.00 & 3946 & 2296 \\
\hline & 1 & 10 & 100 & 0 & 24 & 31 & 313 & 2.31 & 0.06 & 0.82 & 0.00 & 4085 & 2505 \\
\hline \multirow[t]{3}{*}{ Grass } & $\mathrm{C}$ & 38 & 0 & 103 & 25 & 36 & 299 & 0.13 & 0.01 & 0.01 & 0.00 & 2307 & 844 \\
\hline & O & 13 & 14 & 0 & 71 & 0 & 714 & 0.00 & 0.00 & 0.00 & 0.00 & 1221 & 1073 \\
\hline & 1 & 38 & 14 & 89 & 25 & 36 & 714 & 0.13 & 0.01 & 0.01 & 0.00 & 1329 & 1107 \\
\hline
\end{tabular}

45 
Table A2 Emission factors used in crop greenhouse gas (GHG) emission calculations.

\begin{tabular}{llll}
\hline Input & Unit & Emission factor & References \\
\hline Seed & $\mathrm{kg} \mathrm{ha}^{-1}$ & variable & Author calculations \\
Organic $\mathrm{N}\left(\mathrm{N}_{2} \mathrm{O}\right.$ from soil) & $\mathrm{kg} \mathrm{ha}^{-1}$ & $6.16 \mathrm{~kg} \mathrm{CO}_{2}-\mathrm{e} \mathrm{kg}^{-1}$ & De Klien et al. 2006 \\
Inorganic $\mathrm{N}\left(\mathrm{N}_{2} \mathrm{O}\right.$ from soil) & $\mathrm{kg} \mathrm{ha}^{-1}$ & $6.16 \mathrm{~kg} \mathrm{CO}_{2}-\mathrm{e} \mathrm{kg}^{-1}$ & De Klien et al. 2006 \\
Inorganic $\mathrm{N}$ (production) & $\mathrm{kg} \mathrm{ha}^{-1}$ & $6.92 \mathrm{~kg} \mathrm{CO}_{2}-\mathrm{e} \mathrm{kg}^{-1}$ & Anon 2009b \\
$\mathrm{P}\left(\mathrm{P}_{2} \mathrm{O}_{5}\right)$ & $\mathrm{kg} \mathrm{ha}^{-1}$ & $1.69 \mathrm{~kg} \mathrm{CO}_{2}-\mathrm{e} \mathrm{kg}$ & Anon 2009b \\
$\mathrm{K}\left(\mathrm{K}_{2} \mathrm{O}\right)$ & $\mathrm{kg} \mathrm{ha}^{-1}$ & $1.74 \mathrm{~kg} \mathrm{CO}_{2}-\mathrm{e} \mathrm{kg}$ & Anon 2009b \\
Lime (production) & $\mathrm{kg} \mathrm{ha}^{-1}$ & $0.11 \mathrm{~kg} \mathrm{CO}_{2}-\mathrm{e} \mathrm{kg}$ & Anon 2009b \\
Lime $\left(\mathrm{CO}_{2}\right.$ from soil) & $\mathrm{kg} \mathrm{ha}^{-1}$ & $0.44 \mathrm{~kg} \mathrm{CO}_{2}-\mathrm{e} \mathrm{kg}$ & Williams et al. 2006 \\
Herbicide & $\mathrm{kg} \mathrm{ha}^{-1}$ & $5.08 \mathrm{~kg} \mathrm{CO}_{2}-\mathrm{e} \mathrm{kg}$ & Anon 2009b \\
Insecticide & $\mathrm{kg} \mathrm{ha}^{-1}$ & $4.74 \mathrm{~kg} \mathrm{CO}_{2}-\mathrm{e} \mathrm{kg}$ & Anon 2009b \\
Fungicide & $\mathrm{kg} \mathrm{ha}^{-1}$ & $3.30 \mathrm{~kg} \mathrm{CO}_{2}-\mathrm{e} \mathrm{kg}$ & Anon 2009b \\
PRG & $\mathrm{kg} \mathrm{ha}^{-1}$ & $4.70 \mathrm{~kg} \mathrm{CO}_{2}-\mathrm{e} \mathrm{kg}$ & Berry et al.2008 \\
Fuel & $\mathrm{MJ} \mathrm{ha}^{-1}$ & $0.0765 \mathrm{~kg} \mathrm{CO}_{2}-\mathrm{e} \mathrm{MJ}$ & Anon 2009b \\
Machinary & $\mathrm{MJ} \mathrm{ha}^{-1}$ & $0.11 \mathrm{~kg} \mathrm{CO}_{2}-\mathrm{e} \mathrm{MJ}$ & Anon 2009b \\
\hline
\end{tabular}

